Tarih Kültür ve Sanat Araştırmaları Dergisi

Revue des Recherches en Histoire Culture et Art

مجلة البحوث التار بخبة و الثقافبة و الفنبة
Vol. 6, No. 1, February 2017

Copyright (C) Karabuk University

httn://kutaksam.karabuk.edu.tr

\title{
DOI: 10.7596.taksad.v6.i1.707
}

Citation: Ebrahimi, M., \& Taheri, A. (2017). The Tragedy in the Story of Rostam and Sohrab in Ferdowsi's Shahnameh. Journal of History Culture and Art Research, 6(1), 96-105. doi:http://dx.doi.org/10.7596/taksad.v6i1.707

\section{The Tragedy in the Story of Rostam and Sohrab in Ferdowsi's Shahnameh}

\author{
Mokhtar Ebrahimi ${ }^{1}$, Abdollah Taheri ${ }^{2}$
}

\begin{abstract}
Tragedy is a stunning example of confrontation between man and nature along with sadness and consequently fate and life. In tragedy, usually one person (hero) is in the center of the story and all of the stories come together to make the inevitable fate happen for that hero. This inevitable fate is usually along with death or a tragic end which occurs for the hero.

The purpose of poet in tragedy is illustration of an advice for readers after death of the hero. In this article, we have tried to review various aspects of tragic story of Rostam and Sohrab and the way the Master of Tous makes his audience and fans aware of passage of time and the eternal destiny using analytical descriptive method. Undoubtedly, what the ancient Greeks, especially Aristotle have proposed as a definition for tragedy as, is in some cases different from Ferdowsi's view but there is a close consistency between the nature of tragedy and the base of tragedy of Rostam and Sohrab and definition of tragedy.
\end{abstract}

Keywords: Ferdowsi, Epic, Tragedy, Rostam and Sohrab.

\footnotetext{
${ }^{1}$ Assistant professor, shahid chamran university of Ahwaz.

${ }^{2}$ M.A .shahid chamran university of Ahwaz.
} 


\section{Introduction}

Tragedy is an example of the human's struggle with fate and life, tragedy is an example of laughing with grief and doubt in which man laughs over his fate and what comes to him but cannot own and control it. In tragedy, hero follows death (Sohrab follows death) and he does not accept the natural death for giving eternity to others and providing the truth for other people's lives and he rather provides another spiritual meaning for death. He controls the death and leads it to his side and accepts it.

Aristotle (323 BC) states about tragedy in his Poetics: "Tragedy is the imitation of a bad and complete story with certain extent and a beautiful expression which has a same level of beauty in all parts and has dramatic form which glorifies people's emotions”.

Aristotle also believes that the hero should not always be purely good or purely evil (Rostam was not purely good and lied to Sohrab) and should be brought from luck to misery and from top to bottom (Sohrab experienced the contempt of death) which changes key events of his life and makes the path of tragedy to be filled with sadness and this sadness is imposed on the Chieftains. Jean Delaunay (1353 AD) believes that tragedy is the same big disadvantage imposed on the Chieftains which leads to instability of the government and shows endless doubt and misery and the true essence of tragedy is a painful nature. Without a doubt, the stories of both Rostam and Sohrab is filled with sadness and pain imposed on Chieftains and are along with a bitter essence with great dramatic aspects.

Max Weber (1920) believes that power has two aspects: 1. One who imposes his power (Rustam imposes his will) 2. One who suffers from this power (Sohrab suffered and died), the power has been power throughout this story and this is one of the main features of tragedy. Tragedy is the display of serious and important actions which will in total be to the detriment of the hero in which the core of story (PLOT) leads to disaster (CATASTROPHE) which is usually death of hero (Shamisa, 1994: 133).

\section{Definitions and generalities}

Dehkhoda believes tragedy to be taken from Greek word of Teragoyami and believes it to be the same sad stories and poems which are basically the base of historical stories and legends or events.

The definition of drama seems to be different in ancient Greek compared to the art of ancient East. Greek dramatists have considered the feeling of helplessness of man against nature and 
agents of nature to be the subject of their work and writings. The ancient Greeks interpreted nature as a force greater than control and will of man and showed human's helplessness against this force which is interpreted to be fate and destiny. This fate and destiny causes events at any given moment can control man at any time and any place and man and in fact the artist who has created this man (hero) must face this inevitable fate and this is the starting point of tragedy and efforts of man to escape these events creates tragedy.

Aristotle believes that whatever happens to man in tragedy such as physical and spiritual pain and suffering must be the result of his action, for example Christians believe that Christ's crucifixion is not a form of tragedy because Christ himself did not make a mistake and his story is a kind of pain and suffering while we face many mistakes from both Rostam and Sohrab in their story, for example, in their first encounter and wrestling, Sohrab was deceived by words of Rostam and false doctrine created by Rostam in wrestling and let him go or in the story of Sohrab and Gordafarid where Sohrab was again deceived and Gordafarid escaped or event which led Rostam not to recognize his own child and be deceived by others (effect of poetry on people is psychologically important and this truth requires discussion and study on sensual status of reader and is considered as one of the most important sections of psychological criticism and there is no doubt about the existence of this effect) (Zarrinkoub, 1994: 56) and this issue is the effect of poetry on people which is one of the main pillars of tragedy and tragic aspect of a work and all of the Shahnameh from Jamshid and his doomed fate to the story of Zahhak and Manuchehr to death of innocent Iraj to the story of Siavash and failed story of Sohrab are creators of great tragedy of Tous Hakim.

Abdolhossein Noshtin believes: "a play with the main theme and tragic conclusion is considered to be tragedy similar to Othello (Noshtin, 1966: 99). These sad conclusions are the results of interactions between honor and lack of it, war between good and evil and filthiness and lack of it and the real hero in these conflicts is evil, he is the one who causes such sad tragedies and he is the hero of all tears in the end”. Evil will win in mythical expression of the matter, in a war between two good heroes which both represent good and he is the main hero and the viewer has a feeling of lightness after watching the tragedy because he has not suffers such fate” (Shamisa, 1999: 65).

\section{Analysis of the tragic aspects of the story of Rostam and Sohrab}

Herbert Spencer (1893) states: "since man cannot do anything against nature and its factors and events, he should inevitably make solutions and he sometimes cannot find a perspective 
for these solutions because the man himself is born of the same random forces and random factors”. In the story of Rostam and Sohrab, Sohrab is looking for a solution to get rid of Rostam and sometimes Rostam is after Sohrab and is looking for a solution to an extent where Sohrab speaks and says:

Whenever I hear the name of Rostam, it is like I have an old acquaintance in him and he even does not want to fight Rostam while wrestling him (finding solution) or when Rostam becomes tired and injured in his first encounter with Sohrab and is beaten for the first time in his life, he is forced to use deception and lies and is trying to find solution. One of the fundamental differences in Western sense of tragedy with tragedies of Shahnameh is that destiny and fate always has a decisive role in Western tragedies and it can be said that it makes events happen and fate rules the hero but in tragedies of Ferdowsi, it can sometimes be seen that the hero causes a wide range of tragedy by imposing his own actions and he creates tragedy with his folly actions and thoughts.

Aristotle believes that we face six components in tragedy:

1. The main core of story (PLOT) which is regular and logical combination of events

2. The hero of story and its characters (CHARACTER)

3. Thoughts of heroes which lead to actions

4. Expressions, words and articulation which must be harmonious

5. The reputations which are along with each other in tragedy

6. Stage (Shamisa, 2002: 153)

All of the hierarchies and attributes expressed by Aristotle for a complete tragedy can be clearly reviewed in the majority of stories of Shahnameh and its masterpieces in Rostam and even Sohrab and Rostam and Esfandiar, from heroes and characters, dialogues and dramatic aspects of these stories to expressions of Tous Hakim and Thoughts and actions of the characters and heroes of story are reflecting an occurrence of tragedy.

In the following section, we will review factors creating tragedy in story of Rostam and Sohrab. 


\subsection{Arrogance}

One of the main factors that causes the tragedy of Rostam and Sohrab is arrogance, arrogance of both Rostam and Sohrab and this arrogance makes none of them to pay attention to internal and external factors of recognition. Arrogance of Sohrab can be observed in all of his encounters with the other battalions, for example, at the time when he faces Hajir who is Guardian of the White Castle, he says:

Let me visit the king/or I will kill you (Rostam and Sohrab, 1999: 179-180)

And arrogance of Sohrab makes him smiles and attack him:

Sohrab started laughing after this conversation/ and he attacked him (ibid: 181)

Or when Sohrab was facing Gordafarid who was covering her face and Sohrab didn't know he is actually a woman and when he sees her, he treats her with arrogance and ignores her:

When Shohrab saw her/ he started laughing and ignored her

He told her that I will kill you/ with use of my sword and force (ibid, 201-202)

How can this arrogant young hero stop against Rostam since he said to Key Kavous who was the king of Iran:

I will kill you with this spear/ and I will make these labors happy

I swore to do something once in a party/ that person was killed the same night in a war

Even if there is a wasteland left from Iran/I will kill you (ibid, 641-643)

And this arrogance can be seen in Rostam too. When Key Kavous sends Kiv to Zavolestan to make Rostam aware of what imposed in Iranian people by Sohrab, Rostam ignores this message and spends three days for partying and drinking wine:

He said what he heard/ that Sohrab said things like this

But when Rostam heard it/he started laughing to it (ibid, 337-338)

And Rostam ignores Sohrab and says to Giv:

He said too him that/no one can be ca match for me

Which means that there is nobody on earth who can face me

The basic question is that what other than misplaced arrogance has caused such tragedy? Traces of this arrogance which leads to failure emerges in the story of Jamshid Shah which is 
misplaced arrogance and claim by Jamshid to be God or in the story of Esfandiar who thinks he can stop Rostam using force and take him to his father and an arrogance which leads to creation of a bitter tragedy in this way.

\subsection{Destiny and fate}

Zarrinkoub writes: "comparison of the story of Ferdowsi with what Matthew Arnold of England shows from the same concept shows the extent to which Ferdowsi has reach in the artistic climax" (Zarrinkoub, 1964: 23). Rostam and Sohrab is among the most tragic parts of Shahnameh in which the weakness of man against destiny and fate can be observed, a disaster in form of killing your own son by foundation of Shahnameh who is Rostam, what other than destiny and fate can cause such thing?

Nasallah Falsafi writes about the life of Shah Abbas Safavid: "Shah Abbas killed his elder son Safi Mirza due to being suspicious and blinded his other two sons for no reason in a way that he had no son to become his successor at the time of his death" (Falsafi, 1968: 328). These are the game of power and life all of which lead to sad tragedies, Tous hakim says after Sohrab being killed by Rostam:

He ordered others to/ cover the face of his young son

They prepared him/ and brought a coffin

Hey took his coffin away from that plain/ and placed it near the tents

They shed fire on it/ and all of his army were honoring him

The same tent which $\mathrm{t}$ seven colors/ the same golden throne

They shed fire on all of those/ Rostam was extremely sad about it

He was crying blood and was tearing everything apart/ all of his clothes were torn apart

And he says the following:

This is fate/ I cannot do anything about it

No one has control over it/ and we must accept it

And writes about destiny and fate from the words of Bahram Gur which is also the end of story:

Fate is this and we cannot discover its secrets/ you cannot find its key as much as you search 
You cannot open this door/and you will just waste your time

This story is full of sadness/ everyone will be mad of Rostam

However Rostam was trapped by destiny and fate and became a mean for certainty of an inevitable fate.

\subsection{Conflict between thoughts and things that should be done}

Freud believes that man initially lived as packs and sons would kill and eat a powerful father which uses the main share of goods and possesses the females, this event in the beginning of a string from the beginning of social existence to the end (Freud, 1911: 149). It must be understood that events existed from the outset of universe and man and his thoughts and desires are the main actors in all of them. Keyer Gegor (1855) believes: I laughed when I opened my eyes and saw the truth”. The truth about the story of Rostam and Sohrab is that both heroes created the tragedy and sad fate of Sohrab with their arrogance and prejudice and lack of attention to their inner thoughts. Nasrallah Monshi believes people in this world are in three categories (living well - having dignity - living for reward of the hereafter). Indeed, both Rostam and Sohrab had dignity and were living well but they ignored the third factor and did not pay attention to their internal self even though they have been warned many times before. Conflict and lying can even be observed in Hajir when Sohrab asks him to tell where the tent of Rostam is and he says:

He asked about him from Hajir/ but he said he does not know him

I live in this place/ but I do not know where he is

Sohrab said with sadness that/ I could not find Rostam

His mother described his father for him/ he searched for his with those in mind (ibid, 500503)

And Hajjir lies to Sohrab and tells him he is in Zavolestan and he is busy drinking wine. Let's review what Rostam says to Sohrab when Sohrab says are you Rostam?

I think that you are Rostam/you are that famous hero

But Rostam answered that I am not Rostam/ I am not the son of Som

He is a hero and I am not/ he is in a higher level than me (ibid, 680-682) 
Rostam is disappointed with this saying of Rostam and Rostam ignores his inner self, or in another place Sohrab says to Homan:

That hero said to Homan that/ he want to fight me

He is at the same level as me/ he is not afraid of fight

His look and appearance is like me/ it is like he is me

My mother's descriptions fit him/ my heart also says that he is the one

I guess that he is Rostam/ there are few men like him (ibid, 804-808)

And here, Sohrab is trapped by conflict of his thoughts and actions, should I fight or not? Is he Rostam or not? And even Sohrab asks Rostam to stop enmity and hatred and stop fighting. Ferdowsi quotes from Sohrab:

My heart says to me that/ I should stop fighting you

I think you are from the race of battalions/ you said thee yourself (ibid, 825 to 826)

And it is Rostam who ignores everything

\subsection{End of tragedy or disaster}

Death of hero creates the sense of fear and sense of compassion in the reader, the reader cries along with the sadness of Rostam. Fear of such massive event by Rostam which can be considered as the main factor of son-killing tragedy and a sense of compassion toward him for what he has not done on purpose. As expressed by Schopenhauer (1860), tragedy is a great misfortune and this misfortune can be clearly observed in both Rostam and Sohrab.

And Tous Hakim expresses it as follows:

When Rostam returned to his tent/ he placed his son and coffin in front of him

He opened the door of coffin/ and he removed his shroud

He cleansed his body similar to heroes/ it was like the whole world was sad

The whole world was sad about it/ dust took the whole world like a cloud

And the concept of burying the son of Rostam and crying and sadness is a form of tragedy. 


\section{Conclusion}

Tragedy is a drama which shows a part of life of a great hero who has had a catastrophic life and death. Even though the concept of tragedy in Shahnameh stories is different with what Aristotle and the ancient Greeks believe it to be, the fact of the matter is that the story of Rostam and Sohrab is comparable to Greek tragedies in terms of tragic concept and structure. Ferdowsi has tried to show that it is due to fate on one hand and perhaps more importantly, actions of man himself and the fact that lack of attention to inner self and divine messages can be extremely disastrous. Would all of these happen if Hajir would tell the truth to Sohrab? Would such disaster happen if Rostam wouldn't lie and tell the truth when Sohrab asked him if he is Rostam? Or if Kay Kavus would bring panacea on time? Or if Homan and Barman would not conceal some facts? It must be said that these are the nature of a tragic art which occur to be a lesson for others.

\section{Footnotes:}

\section{1-JANE LABORIE}

2-Plays of William Shakespeare's romantic and tragic effect has been written about (1603$1604 \mathrm{M})$

\section{References}

Anvary, H. \& Shoar, J. (1999). Rostam and Esfandiar Epic, Tehran: Drops.

Anvary, H. (1999). Speaks with Culture, Volume 1, Tehran: Statement.

Aristotle (2009). About the Art of Poetry. Translated by M. Sohail, Tehran: Wisdom Publications.

Aristotle (2009). Art of Poem, Translated by Soheil Muhsin Afnan, Tehran: Hekmat Publications.

Chomsky, Noam (1998). The Psychology of Language of Thought, Translated by Kourosh Safavi, Tehran: Agah Press. 
Delacampagne, Christian (2003). A History of Philosophy in the Twentieth Century, Translated by Bagher Parham, Tehran: Agah press.

Gaarder, Jostein (2010). Sophie’s Sufi World: A Novel about the History of Philosophy, Translated by Hassan Kamshad, Tehran: Nilufar Publication.

Gholam Rezaei, M. (2002). The Style of Persian Poetry of Rudaki to Shamloo, Tehran: Heroes.

Hashemi, M. (1970). On the Side of the Medes Iran, Tehran: The Mirror of Knowledge.

Hazrat Hassan (2012). Historian and Historiography, Tehran: Institute of Contemporary History.

Khanlari, Zahra (1962). A Guide to Persian Literature, Tehran: Tehran University Printing.

Magee, Bryan (2007). The Great Philosophers: An Introduction to Western Philosophy, Translated by Ezatollah Folladvand, Tehran: Khwarizmi Press.

Munshi, Abu’l Ma’ali NasrAllah (1994). Panchatantra, the Correction M. Mino, Tehran: Sepehr Publication.

Parsinejad, Iraj (2009). Ehsan Tabari and Literary Criticism, Tehran: Talks.

Rhymy, M. (1990). The Tragedy of Power in the Shahnameh of Ferdowsi, Tehran: Lily.

Safa, Zabihullah (1994). History of Literature in Iran, Summary of Mohammad Torabi, Volume I, Tehran: Phoenix.

Secretary, N. (1994). Panchatantra, Correct Spiritual Mojtaba, Tehran: Sepehr.

Shmysa, S. (1994). General Stylistics, Tehran: Ferdows.

Tafazoli, A. (1997). Literary History of pre-Islamic Iran, Tehran: Statement.

Tanner, Michael (2008). Schopenhauer: Metaphysics and art, Translated by Akbar Masoom Beigi, Tehran: Agah Press.

Zarrinkoub, Abdul (1992). Poet without Lies Unveiled Poetry, Tehran: Scientific Publications.

Zarrinkoub, Abdul (1995). Literary Criticism, Tehran: Amir Kabir. 